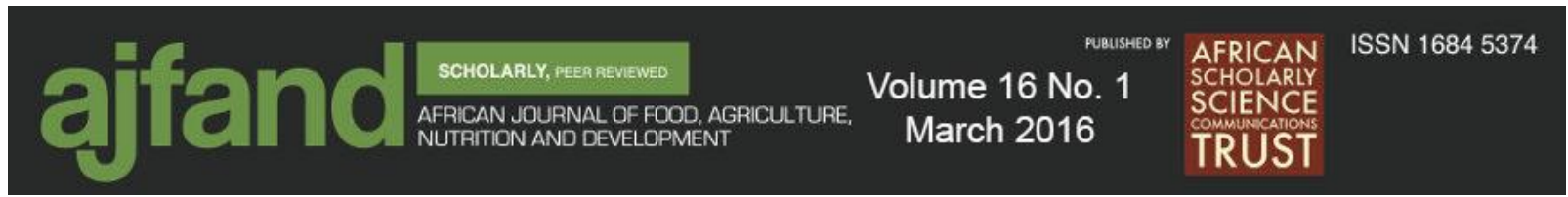

DOI: 10.18697/ajfand.73.15650

\title{
THE PROSPECT OF BIOGAS AMONG SMALL-HOLDER DAIRY GOAT FARMERS IN THE ULUGURU MOUNTAINS, TANZANIA
}

Grimsby LK*1, Gulbrandsen L ${ }^{1}$, Eik LO ${ }^{1}$, Msalya G $^{2}$ and GC Kifaro ${ }^{2}$

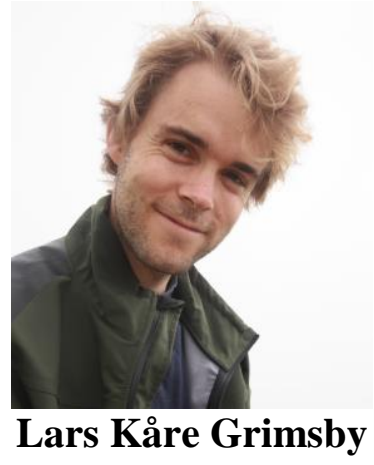

*Corresponding author email: $\underline{\text { lkgrimsby@gmail.com }}$

${ }^{1}$ Department of International Environment and Development Studies/Noragric, Norwegian University of Life Sciences, P.O. Box 5003, 1432 Ås, Norway

${ }^{2}$ Department of Animal Science and Production, Sokoine University of Agriculture, P. O. Box 3004, Morogoro, Tanzania 


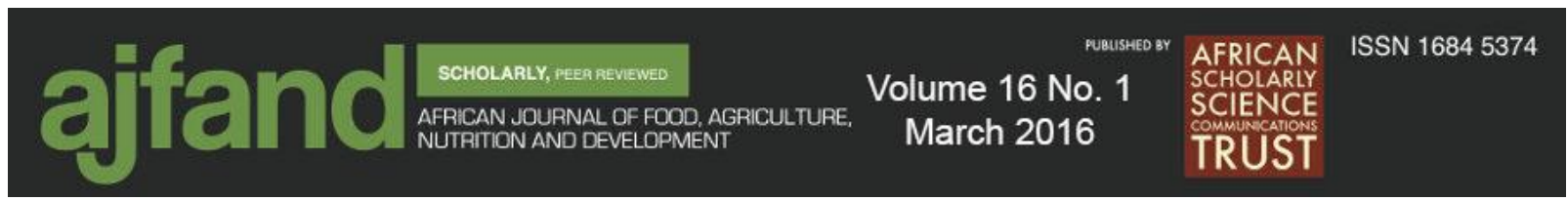

\section{ABSTRACT}

Biogas can be a clean cooking alternative where biomass is the dominant source of cooking energy and where feedstock for anaerobic digestion is available. By substituting woody biomass for energy, biogas may reduce local deforestation. Tanzania has more than $\mathbf{1 5 . 6}$ million goats. Dairy goats of different breeds are found in the mid- to high altitudes of the country. Population density has made firewood increasingly scarce and there are few energy alternatives in mountainous areas such as in the Uluguru Mountains. In Mgeta ward, Morogoro region, introduction of Norwegian dairy goats in the 1980s has improved livelihoods in the area. In this study, goat manure was assessed as feedstock for biogas and as fertilizer. Field work among small-holder dairy goat farmers in Mgeta was conducted to measure daily manure production, and to provide a basic model for prediction of the quantity of droppings which may be collected by farmers. Biogas and fertilizer potential from goat manure was compared to cow and pig manure. Buswell's formula was used to calculate approximate methane yield. The results show that goat manure from Mgeta can yield $1671 \cdot \mathrm{kg}$ Volatile Solids ${ }^{-1}$ (VS). Compared with other substrates approximate methane yield can be ranked as pig > guatemala grass $>$ cow $>$ goat. The average goat of $25 \mathrm{~kg}$ in Mgeta leaves $61 \mathrm{~kg}$ Total Solids (TS) droppings per year. It was estimated that 15 goats'capita ${ }^{-1}$ would be required to meet the total cooking energy needs of small-holder households in the study location. N:P:K content in goat manure (TS) is $2: 1: 1$, similar to cow and pig manure. Goat droppings had to be macerated to reduce particle size for anaerobic digestion. Biogas from dairy goats could be combined with the year-round irrigated horticulture production in Mgeta. Vegetable gardens in the slope below the digesters could be fertilized by gravitation with the $\mathrm{NH}_{4}{ }^{+}$-rich bioslurry, to save labour and increase yields.

Key words: Biogas, bioslurry, goat, manure, dairy, fertilizer, Buswell, Morogoro, Tanzania 


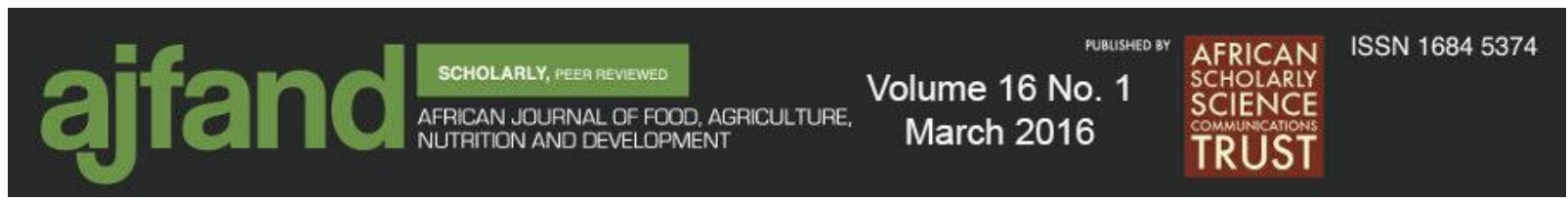

\section{INTRODUCTION}

Biogas can be a clean cooking alternative where biomass is the dominant source of cooking energy and feedstock for anaerobic digestion is available. By substituting woody biomass for energy it may reduce local deforestation. Transition from cooking with wood fuels to biogas may also lessen the burden of fuel collection on women and children. Cleaner indoor air can reduce prevalence of pulmonary diseases and improve the standard of living. Biogas can also be used to improve indoor lighting by substituting candles and kerosene. Though the primary benefit of biogas generally is stated to be cleaner domestic energy supply, high-quality organic fertilizer can be an equally positive output of anaerobic digestion. Macro and micro-nutrients bound as organic matter are mineralised and released through the anaerobic microbial digestion process, thereby enhancing availability of nutrients bound in organic matter to plants.

In Tanzania biogas has been promoted in fragmented initiatives since the 1970s [1]. In 2008 SNV Netherlands Development Organisation (SNV) began a large scale dissemination programme in collaboration with Centre for Agriculture Mechanization and Rural Technology (CAMARTEC), the objective being to construct 12,000 small digesters by 2014 [2]. Rather than being a 'pro-poor' intervention, biogas technology in the Tanzania Domestic Biogas Programme (TDBP) is targeted towards small-holders meeting specific criteria in terms of access to resources and quality livelihoods [3]. Selection criteria in TDBP includes continuous access to water and sufficient amounts of cow manure through stall-feeding rather than grazing [4]. The technical potential for $6 \mathrm{~m}^{3}-13 \mathrm{~m}^{3}$ digesters has been estimated to 165,000 households in Tanzania [5], and regions such as Morogoro have suitable conditions [6]. Goat farmers are not in the target group of development-led biogas interventions, although they constitute a substantial segment of Tanzanian agro-pastoralists. Goat production is important for the economy and food security in Tanzania. It is estimated that there are over 15.6 million goats in the country; about 98\% are local Small East Africa goats [7], and it is estimated that there are 419,533 dairy goats of different breeds. Most of these goats are found in mid- to high altitude areas of the country with over $60 \%$ of the dairy goats being raised in regions of northern Tanzania [8]. Generally, dairy goat breeding offers significant promise to alleviate poverty and malnutrition in most rural families in developing countries [9].

As a potential feedstock for biogas production, goat manure has attracted limited attention. For indigenous goats, the quantity of manure per goat is low, and the manure is dry and hard compared for example to cow and pig manure. Its texture may cause scum formation in biogas digesters and inhibit the process. Mechanical pre-treatment and additional water is required to increase hydrolysis and microbial activity in the digester. For dairy goats on the other hand, when kept on a proper level of nutrition, quantity of manure will be higher and the consistency softer. 

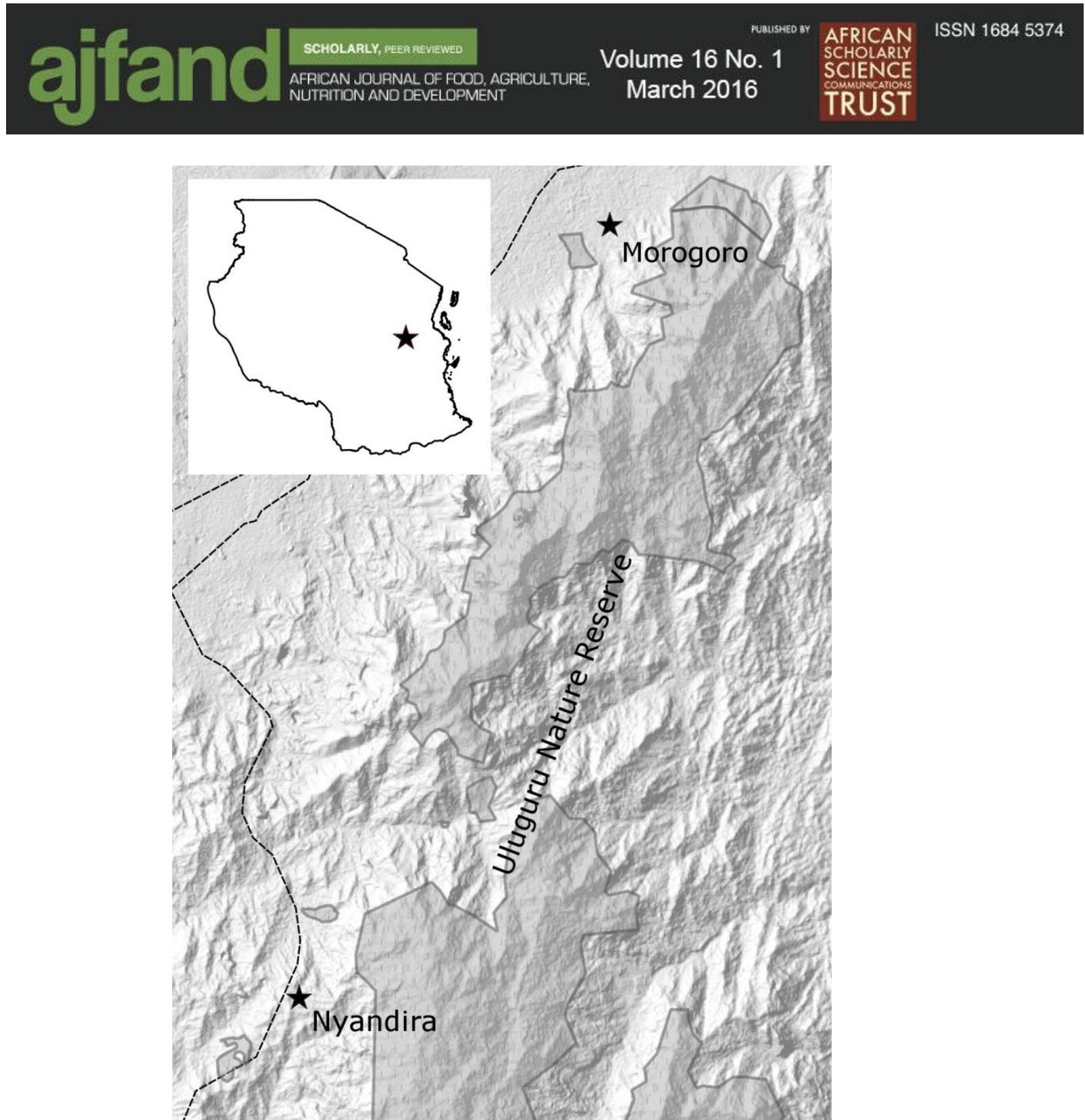

Figure 1: Nyandira village is located south of Morogoro, close to Uluguru Nature

\section{Reserve}

In the steep hillsides of Mgeta ward in the Uluguru Mountains, where Nyandira village is found (Figure 1), a project has been running since the 1980s in which Norwegian goats have been introduced and inter-bred with local goats. Contrary to free-grazing or tethered local goats kept for meat only, dairy goats are kept in a semi-intensive system which involves supplementation indoors thus making manure collection feasible. The goat pens are raised above the ground to allow droppings to fall through the floorboards. It increases cleanliness and reduces risk of disease. It also enables collection of goat droppings for use in agriculture for soil improvement and organic fertilizer. Small-holder goat farmers typically diversify their livelihoods, combining livestock keeping and crop farming. The local climate in Mgeta together with increasingly accessible irrigation technology allows year-round vegetable production. Goat droppings may therefore be added regardless of seasons, as fertilizer. This reduces the need for expensive storage facilities for the digestate. 


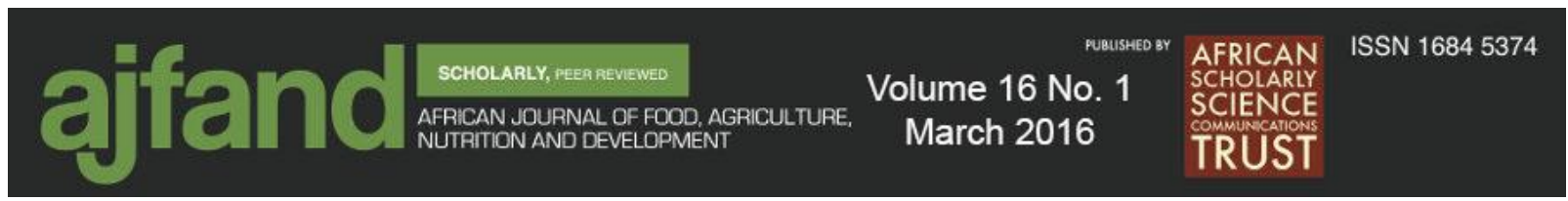

With one exception, conditions in Mgeta including environmental endowments and farmers' livelihood strategies conform to the criteria for successful adoption of biogas technology. There are no cattle in Mgeta. Due to the landscape and cultural background, cattle and dairy production have not been practiced by native inhabitants of Morogoro known as Luguru. If biogas based on goat manure proved to be a viable option, it could open up for use as clean energy and alternative fertilizer by many more households. This study investigated how much goat manure could be collected from goat pens of small-holder dairy goat farmers in Mgeta ward, Morogoro region, Tanzania. Goat manure was also assessed as feedstock for biogas and as fertilizer, in light of the local context of the Uluguru Mountains. The theoretical biogas and fertilizer potential from goat manure was compared with those of cow and pig manure.

\section{MATERIALS AND METHODS}

Nyandira village ( 1,600 m.a.s.1.), Mgeta ward, where the field study was conducted, is located on the western side of the Uluguru Mountains (Figure 1). Most of the Uluguru Mountains are characterised by steep, cultivated hillsides. Water is increasingly accessible through provisory irrigation channels and hoses from streams originating in the forested nature reserve along the top of the Uluguru Mountain range. Irrigated agriculture and increasing market access to Dar es Salaam has made vegetable production in this region attractive. Scarce available land and erosion of nutrients and organic matter from the soil has made abatement measures pertinent.

Goat droppings were collected among small-holder dairy goat farmers. Sampling of farmers was purposive aimed at having a wide range in number of goats in each pen, to support linear regression analysis of manure generation against weight $(\mathrm{kg})$ of goats. The study took place over three consecutive days in March 2014. Manure was collected from 13 goat pens with a total of 91 goats, and 1 sheep. The pens were built on poles $0.5 \mathrm{~m}-1.0 \mathrm{~m}$ above ground. Floors were made from logs or boards to allow droppings and urine to fall through and keep the floor dry.

In order to develop a model for prediction of goat manure production, wet weight of goat manure from the 13 pens was measured over three consecutive days. To collect droppings and urine tarpaulins were fixed under the floors; their sizes measured to obtain area of the pens' floors. Manure production was measured each day by weighing wet weight samples including urine and rain water that might have leaked through the roof. Sub-samples were taken from each tarpaulin and analysed for Total Solids (TS) content. All the animals were weighed and their breed and sex recorded.

Field measurements of wet weight manure was done on a EK01 digital scale with range from $2 \mathrm{~g}$ to 5,000 g. Weight of goats was measured by lifting them in an improvised sack attached to a $0 \mathrm{~kg}$ to $100 \mathrm{~kg}$ Hanson No. 21 hanging scale. The TS content was measured by drying at $105{ }^{\circ} \mathrm{C}$ in an oven overnight. Ash content of TS was measured by Loss of Ignition at $550{ }^{\circ} \mathrm{C}$. Chemical Oxygen Demand (COD) was measured by titration with potassium dichromate according to standard methods by APHA (1992). Neutral Detergent Fibre (NDF), Acid Detergent Fibre (ADF) and Acid Detergent 


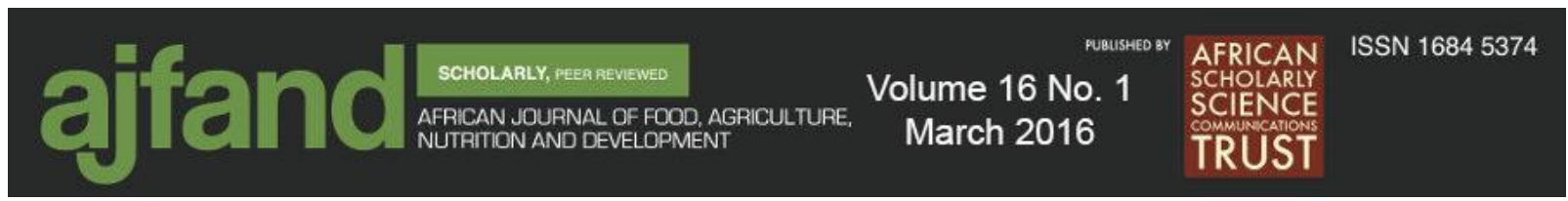

Lignin (ADL) were measured according to standard protocols [10]. Total nitrogen (Kjeldahl), total phosphorus and extractable potassium of the substrates were measured according to AOAC standards.

A batch trial experiment was set up to assess to what extent whole goat droppings dissolve in methanogenic culture. Substrate and inoculum were diluted to a total of $1 \%$ Volatile Solids (VS) in a total mass of $700 \mathrm{~g}$ in 1L bottles capped with rubber stoppers. An inoculum: substrate ratio of 1 was used, thus each bottle contained substrate and inoculum each equivalent to $3.5 \mathrm{~g}$ VS. Inoculum was fresh cow manure from Magadu farm at Sokoine University of Agriculture (SUA). Whole goat droppings were added to the flasks. Batch reactors were incubated at $35{ }^{\circ} \mathrm{C}$ in an incubator with shaking table rotating at $60 \mathrm{rpm}$. The reactors were incubated 50 days from 25 March to 13 May 2014. Pressure was released from the reactors every two to four days.

Four potential substrates for anaerobic digestion available in the study area were analysed for approximate biogas yield and methane content. Pig manure, guatemala grass (Tripsacum andersonii) and goat manure were obtained in Mgeta. Cow manure was obtained from SUA's research farm in Morogoro. Microcrystalline cellulose (Merck) was included as reference material. Potential methane yield by VS was calculated as exemplified by Schnürer and Jarvis [11]. They used a method for calculating theoretical biogas yield and methane content of carbohydrates, fats and proteins [12, Appendix 4], based on the 'Buswell equation' [13]. The NDF, ADF and ADL were used to calculate cellulose (ADF-ADL) and hemicellulose (NDF-ADF) content in substrates. Protein content was calculated as Kjeldahl $\mathrm{N} \times 6.25$.

Descriptive and associative statistics were made in Microsoft Excel and R statistical software. Statistical methods include ANOVA and linear regression.

\section{RESULTS}

The goat pens in the study had mean area of $9.5 \mathrm{~m}^{2}$ (S.D. \pm 4.4 ) and ranged from $1.1 \mathrm{~m}$ $\times 1.8 \mathrm{~m}$, to $1.8 \mathrm{~m} \times 4.3 \mathrm{~m}$. Number of goats kept per pen ranged from 2 to 16 , with a mean of 7 (S.D. \pm 5 ). This gave $0.7 \mathrm{~m}^{2}$ floor space for each goat. The farmers reported that they grazed their goats between 0 and 8 hours per day, mean hours being 5 . Feeding by grazing was complemented with freshly cut grass and water placed in the pens. Guatemala grass was a common feed. Goat droppings were left to decompose under the pens for use as fertilizer when required, but without active composting. Personal communication with research staff at SUA suggests that such storage under the pens and application in agriculture was common practice in the study area.

Goats were weighed and their breed recorded as shown in Table 1. An ANOVA test did not show significant difference $(p>0.05)$ in mean weight across local, cross-bred, and Norwegian pure breeds. Mean weight of all goats in the study was $25 \mathrm{~kg}$ (S.D. \pm 12 ). Ratio of does to bucks was $4: 1$. 

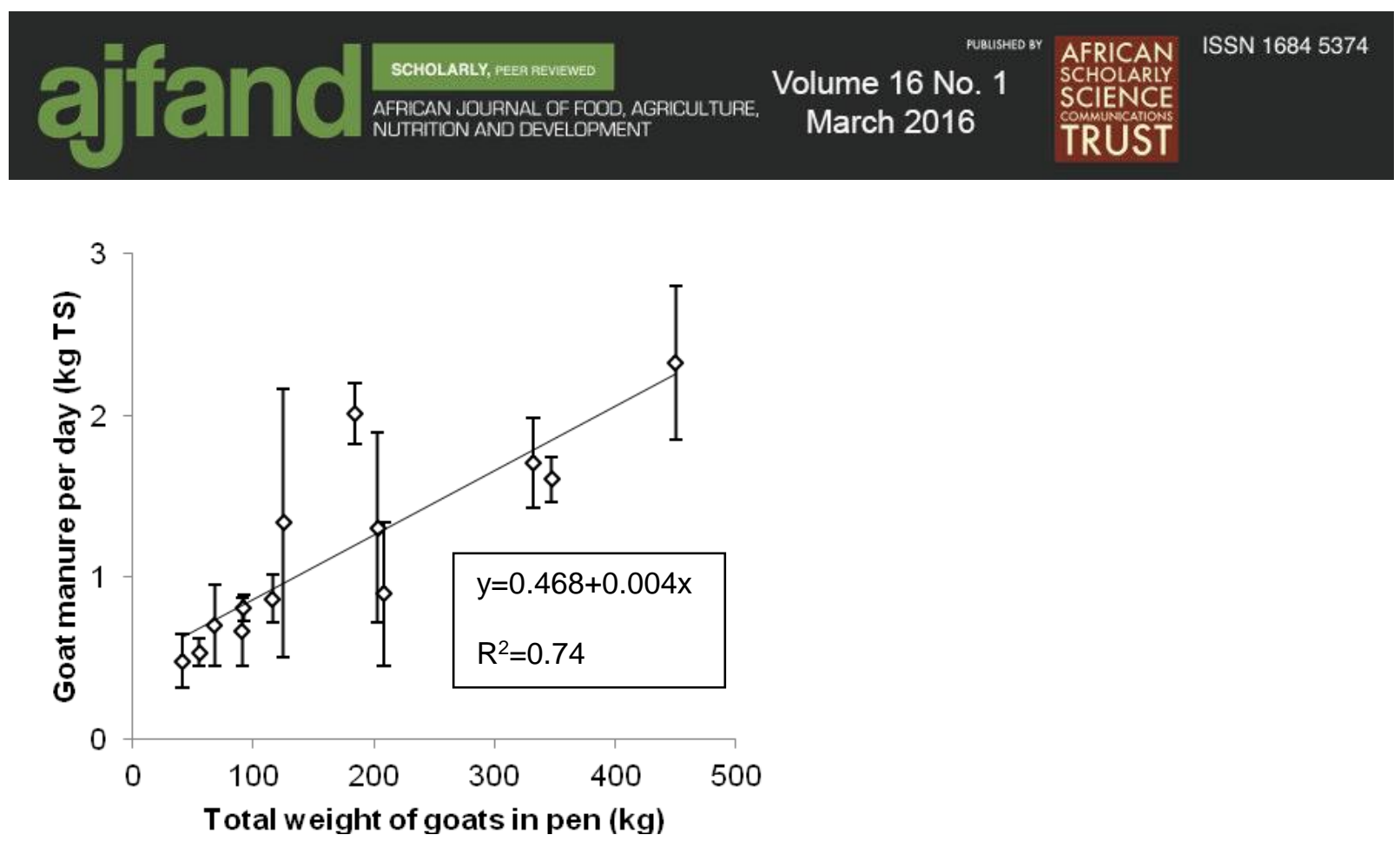

Figure 2: Quantity of goat manure (kg TS·day $\left.{ }^{-1}\right)$ plotted against total weight of goats in pen (kg) with Standard Deviations.

Collective weight of goats for individual pens ranged from 40 to $480 \mathrm{~kg}$. Participating farmers were selected specifically on the basis of providing a wide range in number of goats per pen (Figure 2), in order to develop the regression model in Equation 1:

Equation 1: $\mathrm{kg}$ TS goat manure per day $=0.004 \cdot \mathrm{kg}$ goats +0.468

Equation 1 is significant at $p<0.05$ (F-test), and may be used for prediction of goat manure generation and collection from pens in Mgeta. Mean weight of goats in the study being $25 \mathrm{~kg}$ (Table 1) and mean number of goats per shed 7, Equation 1 predicts that the goat manure available to the average goat farmer in Mgeta is: 0.004(25.7) + $0.468=1.2 \mathrm{~kg}$ TS goat manure $\cdot$ day $^{-1}$.

It is worth noting that TS on average was $23 \%$, ranging from $2 \%$ to $43 \%(n=73)$ in the sub-samples of goat droppings collected from the pens to calculate Equation 1. Data collection took place during rainy season, and the samples were moist from rainwater that had leaked through holes in the tin roofs over the sheds. In contrast, goat manure collected for approximate methane yield analysis had 50\% TS (Table 2). These samples were collected during a drier period, towards the end of the rainy season. Cow manure had the highest water content, with only $19 \%$ TS. Goat manure had high COD relative to the other animal manures. Pig manure contained more ash, reflected in the relatively low VS.

Plant macro nutrient content in the substrates subject to approximate methane yield analysis can be compared in Table 3 . The relative fertilizer value of goat manure can be calculated as follows: $6 \mathrm{~kg}$ goat manure would supply the same amount of $\mathrm{N}$ as $1 \mathrm{~kg}$ 15:15:15 N:P:K fertilizer. Similarly, $25 \mathrm{~kg}$ and $17 \mathrm{~kg}$ goat manure would supply $\mathrm{P}$ and 


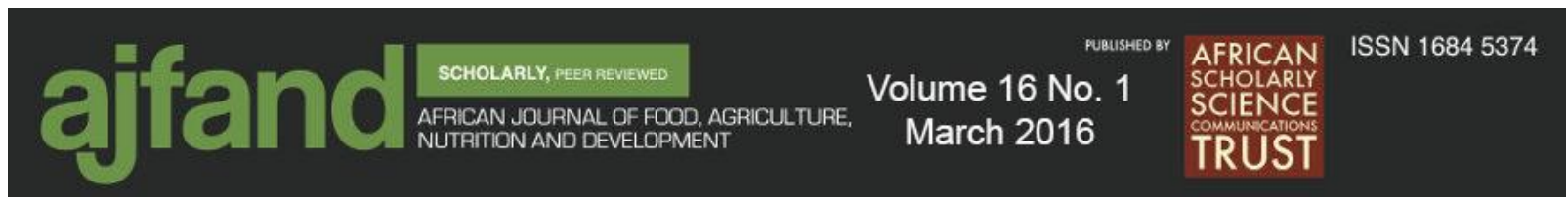

$\mathrm{K}$ equivalent $1 \mathrm{~kg}$ to inorganic fertilizer. Guatemala grass contains much $\mathrm{K}$, and cow manure less $\mathrm{N}$ than the other substrates.

Table 4 presents carbohydrate composition of the four substrates, based on values obtained from chemical analysis of NDF, ADF and ADL. Degradability of substrates is important for their quality as feedstock in anaerobic digestion to produce biogas. Guatemala grass had the highest quantity of hydrolysable hemicellulose. Goat dung had high lignin content compared with other substrates.

Calculating approximate methane yields (Table 5) revealed that of the four substrates, goat droppings had the lowest potential and pig manure the highest. Methane yields ranged between $1671 \cdot \mathrm{kg} \mathrm{VS}^{-1}$ and $2201 \cdot \mathrm{kg} \mathrm{VS}^{-1}$. Concentration of methane in the biogas was calculated to $52 \%-53 \%$.

Adjusting approximate methane yield of $1671 \cdot \mathrm{kg} \mathrm{VS}^{-1}$ (Table 5) for $83 \% \mathrm{VS}_{(\mathrm{TS})}$ (Table 2 ), and assuming that the average goat leaves $61 \mathrm{~kg}$ TS droppings per year, each goat can supply $8.5 \mathrm{~m}^{3} \mathrm{CH}_{4}$, or $306 \mathrm{MJ}$, annually.

Batch reactor trials to test the physical strength of goat droppings' texture showed that while gas production in bottles with whole goat droppings was high under anaerobic conditions, the droppings had not auto-dissolved and were still afloat in the reactors after 50 days' incubation.

\section{DISCUSSION}

Field observations and experiments show that from stall-fed goats in Nyandira, $61 \mathrm{~kg}$ TS droppings could be gathered per year. One goat could leave manure sufficient to generate $8.5 \mathrm{~m}^{3} \mathrm{CH}_{4}$, or $306 \mathrm{MJ}$, annually. Goat manure was shown to have an N:P:K ratio of $2: 1: 1$, which was similar to the $\mathrm{N}: \mathrm{P}: \mathrm{K}$ ratios of cow and pig manure. This section discusses the findings in relation to other research, and implications of the findings for the viability of biogas technology among dairy goat farmers in the Uluguru Mountains.

The quantity of goat droppings collected during the field research in Nyandira corresponds with $166 \mathrm{~g}$ TS$\cdot$ goat $^{-1} \cdot \mathrm{day}^{-1}$, or $61 \mathrm{~kg} \mathrm{TS} \cdot \mathrm{goat}^{-1} \cdot \mathrm{year}^{-1}$. Manure production from grazed Red Sokota Goats in Nigeria was $138 \mathrm{~kg} \cdot \mathrm{head}^{-1} \cdot \mathrm{year}^{-1} \mathrm{TS}$ [14]. Completely stall fed kids in New Zealand produce about $300 \mathrm{~kg} \cdot \mathrm{head}^{-1} \cdot \mathrm{year}^{-1}$ containing $30 \%$ to $37 \%$ TS [15], which is equivalent to approximately $100 \mathrm{~kg} \mathrm{TS} \cdot \mathrm{head}^{-1} \cdot \mathrm{year}^{-1}$. The relatively low manure production in Mgeta can be attributed to their feed which does not have any supplements such as molasses and protein, and to the fact that the goats are grazed on average 5 hours per day and droppings during this time remain in the fields. Since the introduction of Norwegian dairy goats in the 1980s, dairy goat keeping has become increasingly popular resulting in high prices of live animals. Because sale of animals is more profitable than sale of milk, farmers keep more goats under a lower plane of nutrition, resulting in less manure per goat as reflected in this study. 


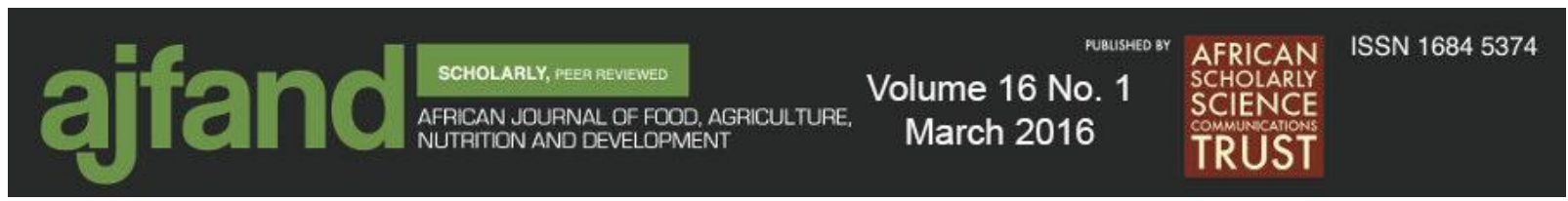

Goat manure's TS content of $23 \%$ in this research is low compared with other studies. Zhang et al. [16], for example, found $33.65 \%$ TS in their goat manure in China. Similarly, 34\% is reported in New Zealand [15]. The long rainy season in the Uluguru Mountains typically lasts from February to May, and this study was conducted in March. Low TS was caused by rain entering the sheds and increasing the moisture content of the droppings. However, goat droppings collected when there was no rain, as shown in Table 2, had a TS content of 50\%. This value can be assumed to be closer to values expected during the longer-lasting dry season in the Uluguru Mountains. Water content is an important factor in anaerobic digestion of organic matter. Water helps degrade the material through hydrolysis; it increases the surface of the material and creates viable conditions for microbial activity [11]. In full-scale digesters, a TS content below $10 \%$ is not uncommon, although Biochemical Methane Potential assays operate with a concentration of only $1 \%$ VS [17]. Assuming a TS content of $23 \%$ as observed during field work in the rainy season, 1.3 parts of water would have to be added to each part of goat droppings. If TS content is 50\% (Table 2), 5 parts of water will have to be added per part goat droppings to reduce TS level to $10 \%$ to optimize methane yields. Water requirement has been shown to be a critical factor for the viability of biogas in Tanzania [18]. In the Uluguru Mountains, water is available throughout the year.

Goat manure had an $\mathrm{N}: \mathrm{P}: \mathrm{K}$ ratio of $2: 1: 1$, similar to cow and pig manure (Table 3 ). Values correspond with findings elsewhere in Africa [14, 19]. Farmers in Mgeta ward with dairy goats are encouraged to use goat manure directly or composted as fertilizer, and this is commonly practiced. The relatively high TS content makes it less cumbersome to carry and spread the manure on fields than for example pig and cow manure. Anaerobic digestion of organic matter to biogas may mineralise $2 / 3$ of the organically bound nitrogen to ammonium $[11,20]$, and increases concentration of plant nutrients relative to TS. This enhances the fertilizer quality of organic waste, and can make the digestate attractive in agro-pastoral farming systems.

Approximate methane yield from the analysed substrates (Table 5) suggests that goat manure does not perform very well compared with the other substrates (pig > guatemala grass $>$ cow $>$ goat). One explanation for this is found in the slightly lower cellulose content in goat manure, as shown in Table 4. Theoretical yields based on the Buswell equation commonly overestimate potential methane yields [17]. The approximate methane yields of substrates from Mgeta and Morogoro on the contrary are within range of general values [11], although towards the lower end. Calculations are based on theoretical yields only from carbohydrate and protein fractions, which exclude fats. On the other hand, the Buswell equation has been critiqued for overestimating since it by elemental analysis also includes carbon, hydrogen and oxygen in lignin [17]. This is not the case with the approximate methane yield method used here. Fat content is likely to be marginal in manure from livestock among farmers who give no feed supplements. Inclusion of fat would have increased methane concentrations than 53\% (Table 5). 


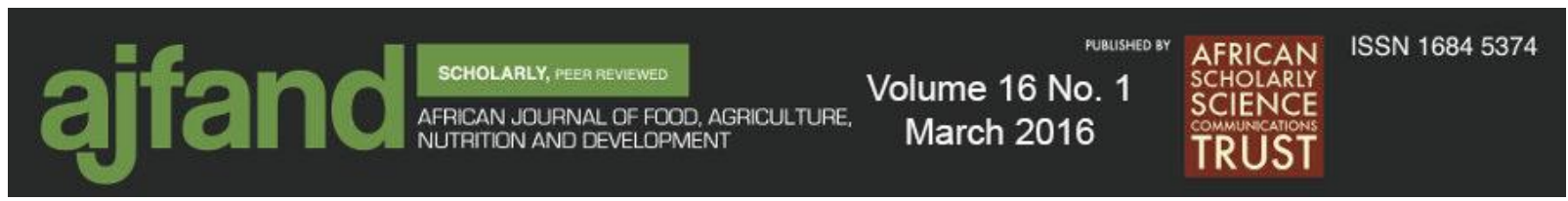

It was calculated that one goat per year could leave collectable droppings equal to biogas with an energy content of 306 MJ. Farmers in the study on average had 7 goats. A recent study from the Southern Highlands in Tanzania estimated annual energy

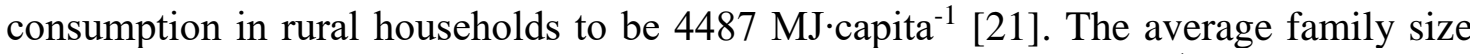
in Morogoro region is five persons [6]. This means 15 goats $^{\prime}$ capita $^{-1} \times 5$ capita $=75$ goats would be required to meet all the cooking and heating energy needs of a household.

The anaerobic stirred reactor trial in the laboratory showed that even after 50 days, the goat droppings with 50\% TS still maintained their shape and floated. This could be due to gas generation within the droppings which reduced their density. Compared with pig and cow manure, goat droppings have hard texture. Particle size has been shown to have a direct impact on digestibility of organic matter [22-24]. Even with relatively liquid cow manure, scum formation is not an uncommon problem with unstirred digesters such as those promoted in East Africa [25]. To avoid "constipated" digesters and to increase methane yields, goat droppings will have to be macerated to reduce particle size and break up their impenetrable solid round structure. The European Union has standardised the maximum particle size to $12 \mathrm{~mm}$ [11], but this does not suffice for goat droppings usually with a smaller size.

Application of semi-composted goat manure as fertilizer is already common practice in the Uluguru Mountains. The research project "Up-scaling of pro-poor innovative dairy goat technologies for improved livelihood security and human capacity in selected highland areas" includes a component of investigating effects of use of composted goat manure in Uluguru Mountains. Preliminary findings show that $82 \%$ of the respondents used goat manure to fertilize vegetables, maize and potatoes. $32.4 \%$ of the farmers used goat droppings to improved yields of vegetables (Unpublished data). Goat droppings used as fertilizer have been shown to give higher yields of Amaranthus than cow manure [22]. Use of digestate from anaerobic digestion of goat droppings and other waste could increase crop yields further, and very positive effects have been seen from application of digestate as fertilizer among small-holder dairy cow farmers in Tanzania [3]. There may be less to gain from substituting mineral fertilizer with digestate [18]. Whether application of bioslurry is a beneficial contribution to farm households depends on how their livelihoods are organised and should be subject to scrutiny if considering whether to obtain a biogas digester or not. This could be part of selection criteria for choosing what farmers to involve in a biogas projects. Low TS content of the bioslurry, for example, makes transport and spreading labour intensive. Potential users of biogas in Mgeta would benefit from combining dairy goats with year-round horticulture production. This would avoid costly storage tanks. Instead vegetable gardens established in the slope below the digesters could be fertilized and to some extent watered with digestate by gravitation.

Biogas from goat droppings is a technical possibility, and can be beneficial in a range of ways in the livelihoods of dairy goat farmers around the Uluguru Mountains and elsewhere. An obstacle to dissemination of biogas technology could be investment costs. The TDBP for example installs $6 \mathrm{~m}^{3}$ and $13 \mathrm{~m}^{3}$ for US\$ 750 and US\$1,050, and 


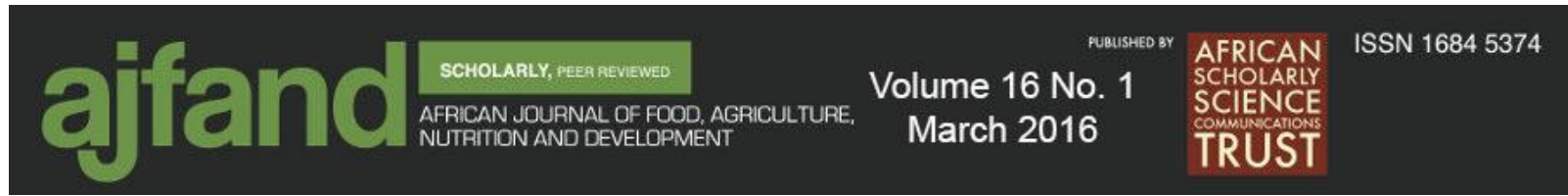

it has been suggested that dairy cow farmers are relatively well off relative to other members of their community [26]. Biogas may be an additional incentive for investing in more dairy cattle, thereby indirectly benefiting the farmer [3]. Considering that 15 goats $^{*}$ capita $^{-1}$ would be required to meet all energy needs, and that the average stock is 7 goats per household, biogas is an unlikely candidate to substitute all the energy needs of small-holder dairy goat farmers. Increasing the flock to perhaps 50 animals solely for the purpose of generating energy, would not be rational. However, use of multiple fuels households' kitchens is common practice in Tanzania, and biogas could be an addition to the present energy mix of firewood, charcoal and kerosene.

\section{CONCLUSION}

This study has shown that biogas and bioslurry may be generated from goat droppings to provide energy and fertilizer. Biogas could complement firewood, charcoal and kerosene for cooking. In the steep hillsides of Mgeta where water is available throughout the year, bioslurry could fit well with year-round intensive vegetable production. It is unlikely that a goat farmer could carry the economic burden of investing in biogas, though the returns may make the investment worthwhile over time. A practical experiment with biogas would give more conclusive evidence of whether biogas is a technology suited as a component in the livelihoods of small-holder dairy goat farmers in Mgeta.

\section{ACKNOWLEDGEMENTS}

We would like to thank the Climate Change Impacts, Adaptation and Mitigation (CCIAM) programme for financial support. We also thank Mr. Solomon Nicolaus for help with field work and data collection in Mgeta, and Dr. Jilisa K. Mwalilino, Mr. Thadeo Filbert Sogomba, Mr. Dominick Allute and Mrs. Consolatha J. N. Mhaiki for making laboratory facilities available. 


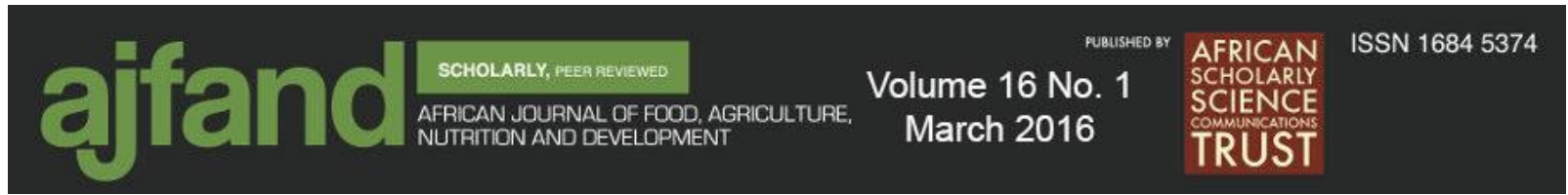

Table 1: Weight and number of livestock in the study. Standard Deviation (S.D.)

\begin{tabular}{lccc}
\hline Breed & $\begin{array}{c}\text { Frequency } \\
\text { Weight, mean }\end{array}$ & $\begin{array}{c}\text { S.D. } \\
\text { kg }\end{array}$ \\
\hline Local goats $^{*}$ & 10 & 29 & 9 \\
Norwegian goats* & 69 & 25 & 12 \\
Cross-bred goats & 12 & 24 & 15 \\
Sheep & 1 & 25 & - \\
Total sample of goats & & & \\
*ANOvA: $>0.05$. & $\mathrm{n}=91$ & 25 & 12 \\
\hline
\end{tabular}

Table 2: Total Solids (TS), Volatile Solids (VS) and Chemical Oxygen Demand (COD) of substrates in Morogoro

\begin{tabular}{lccc}
\hline \multirow{2}{*}{ Substrate } & TS & COD $_{(\mathbf{T S})}$ & $\mathbf{V S}_{(\mathbf{T S})}$ \\
\cline { 2 - 4 } & $\boldsymbol{\%}$ & $\boldsymbol{\%}$ & $\boldsymbol{\%}$ \\
\hline Cellulose & 96 & $59^{*}$ & 100 \\
Goat droppings & 50 & 40 & 83 \\
Pig manure & 26 & 28 & 69 \\
Guatemala grass & 22 & 24 & 91 \\
Cow dung & 19 & 14 & 83 \\
\hline *Theoretical & & &
\end{tabular}

Table 3: Nitrogen $(\mathrm{N})$, phosphorus $(\mathrm{P})$, potassium $(\mathrm{K})$ and ammonium content $\left(\mathrm{NH}_{4}-\mathrm{N}\right)$ in substrates

\begin{tabular}{|c|c|c|c|c|}
\hline Substrates & $\begin{array}{l}\mathbf{N} \\
\% \\
\end{array}$ & $\begin{array}{l}\mathbf{P} \\
\% \\
\end{array}$ & $\begin{array}{l}\mathbf{K} \\
\% \\
\end{array}$ & $\begin{array}{c}\mathrm{NH}_{4}-\mathrm{N} \\
\mu \mathrm{gN} / \mathrm{g} \\
\end{array}$ \\
\hline Guatemala grass & 2.59 & 0.20 & 3.13 & 118 \\
\hline Goat droppings & 2.31 & 0.59 & 0.86 & 403 \\
\hline Pig manure & 2.28 & 0.72 & 1.94 & 63 \\
\hline Cow dung & 1.82 & 0.22 & 1.00 & 29 \\
\hline
\end{tabular}




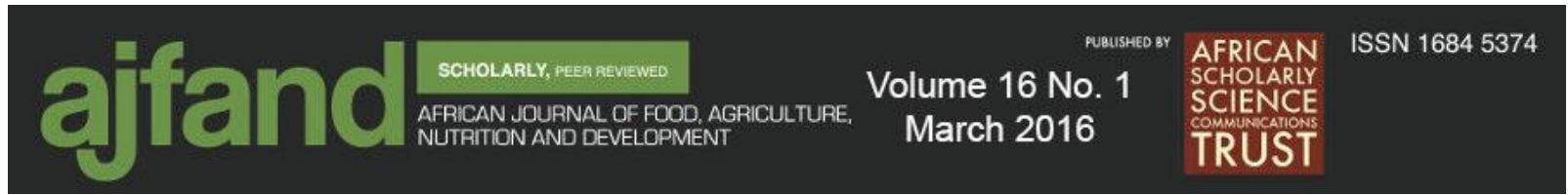

Table 4: Degradable and recalcitrant fractions of substrates. All fractions as percent of TS

\begin{tabular}{lcccc}
\hline Substrates & $\begin{array}{c}\text { Hemi- } \\
\text { cellulose }\end{array}$ & Cellulose & Lignin & Ash \\
\cline { 2 - 5 } & $\%$ & $\%$ & $\%$ & $\%$ \\
\hline Guatemala grass & 40 & 30 & 8 & 9 \\
Goat droppings & 28 & 21 & 21 & 8 \\
Cow dung & 28 & 28 & 10 & 17 \\
Pig manure & 27 & 29 & 10 & 31 \\
Cellulose & - & 100 & - & - \\
\hline
\end{tabular}

Table 5: Approximate methane yields and concentration

\begin{tabular}{lcc}
\hline Substrate & \multicolumn{2}{c}{$\mathrm{CH}_{\mathbf{4}}$ in biogas } \\
\hline & $\mathrm{l} \cdot \mathrm{kg} \mathrm{VS}^{-1}$ & $\%$ \\
\cline { 2 - 3 } Pig manure & 220 & 53 \\
Guatemala grass & 204 & 52 \\
Cellulose & 190 & 50 \\
Cow dung & 173 & 52 \\
Goat droppings & 167 & 53 \\
\hline
\end{tabular}




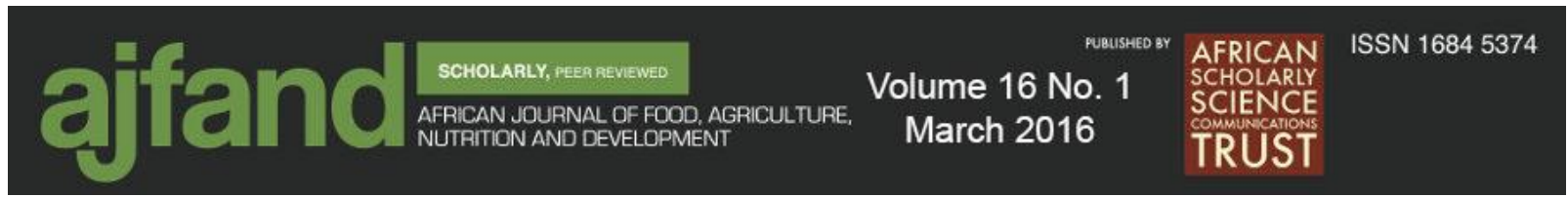

\section{REFERENCES}

1. Mwakaje AG Dairy Farming and the Stagnated Biogas Use in Rungwe District, Tanzania: An Investigation of the Constraining Factors. In: Sunil Kumar (Ed). Biogas: InTech; 2012: 311-327.

2. van Nes W, Lam J, ter Heegde F and F Marree Building Viable Domestic Programmes: Success Factors in Sector Development. SNV Netherlands Development Organisation, 2009.

3. Akyoo AM and OJ Kileo Biogas User Survey (BUS) Analysis Report. Arusha: Tanzania Domestic Biogas Programme, 2012.

4. Landi M, Sovacool BK and J Eidsness Cooking with gas: Policy lessons from Rwanda's National Domestic Biogas Program (NDBP). Energ. Sustain. Dev. 2013; 17: 347-356.

5. Ng'wandu E, Shila LC and FEW ter Heegde Tanzania Domestic Biogas Programme. 2009.

6. Mkiramweni L and I Mshoro Estimating the Potential for Biogas Production and Application in Morogoro Region, Tanzania. Energy and Environment. 2009; 21: 1357-1368.

7. MLFD Budget speech of the Ministry of Livestock and Fisheries Development.2014 Accessed on 5th February 2015. Available from: http://www.mifugouvuvi.go.tz/budget-speech-20122013/.

8. $\quad$ NBS Basic facts and figures on human settlements. Tanzania mainland 2009. 2012. Accessed on 17th February 2015. Available from: http://www.nbs.go.tz/takwimu/references/Facts_and_Figures_on_Human_Settle ments_2012.pdf.

9. Eik L, Kifaro G, Kiango S, Nordhagen $\varnothing$, Safari $\mathbf{J}$ and $\mathbf{L}$ Mtenga Productivity of goats and their contribution to household food security in high potential areas of East Africa: A case of Mgeta, Tanzania. Afr. J. Food Agric. Nutr. Dev. 2008; 8: 278-290.

10. Van Soest PJ, Robertson JB and BA Lewis Methods for Dietary Fiber, Neutral Detergent Fiber, and Nonstarch Polysaccharides in Relation to Animal Nutrition. J. Dairy Sci. 1991; 74: 3583-3597.

11. Schnürer A and $\AA$ Jarvis Microbiological handbook for biogas plants Swedish Waste Management U2009:03, Swedish Gas Centre Report 207. Avfall Sverige, Svenskt Gastekniskt Center AB, 2009.

12. Berglund $\mathbf{M}$ and $\mathbf{P}$ Börjesson Energianalys av biogassystem. IMES/EESS Report No 44: 2003.

13. Symons G and A Buswell The methane fermentation of carbohydrates1, 2. J. Am. Chem. Soc. 1933; 55: 2028-2036. 


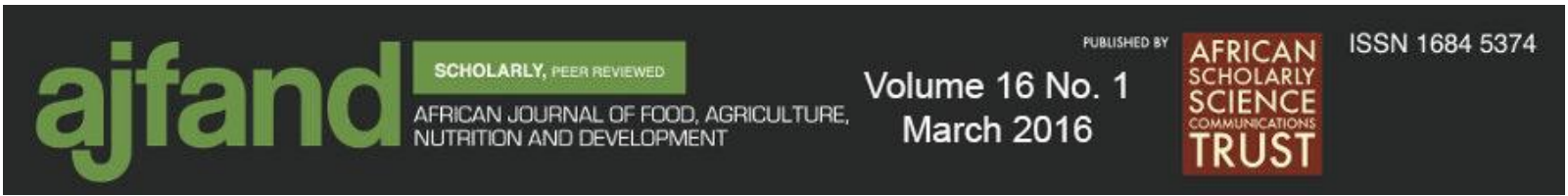

14. Osuhor C, Alawa J and G Akpa Research note: Manure production by goats grazing native pasture in Nigeria. Trop. Grasslands. 2002; 36: 123-125.

15. DGC A guide to managing barn manure on dairy goat farms. AgResearch, Environment Waikato, Dairy Goat Co-operative (N.Z.) Ltd, 2010.

16. Zhang T, Liu L, Song Z, Ren G, Feng Y, Han X and G Yang Biogas Production by Co-Digestion of Goat Manure with Three Crop Residues. PLoS ONE. 2013; 8: e66845.

17. Labatut RA, Angenent LT and NR Scott Biochemical methane potential and biodegradability of complex organic substrates. Bioresource Technol. 2011; 102: 2255-2264.

18. Mwakaje AG Dairy farming and biogas use in Rungwe district, South-west Tanzania: A study of opportunities and constraints. Renew. Sust. Energ. Rev. 2008; 12: 2240-2252.

19. Maerere A, Kimbi G and D Nonga Comparative effectiveness of animal manures on soil chemical properties, yield and root growth of amaranthus (Amaranthus cruentus 1.). Afri. J. Sci. Tech. 2001; 1(4): 14-21.

20. Grimsby LK, Fjørtoft $\mathbf{K}$ and JB Aune Nitrogen mineralization and energy from anaerobic digestion of jatropha press cake. Energ. Sustain. Dev. 2013; 17: 35-39.

21. Menéndez A and MD Curt Energy and socio-economic profile of a small rural community in the highlands of central Tanzania: A case study. Energ. Sustain. Dev. 2013; 17: 201-209.

22. Mshandete A, Björnsson L, Kivaisi AK, Rubindamayugi MS and B Mattiasson Effect of particle size on biogas yield from sisal fibre waste. Renew. Energ. 2006; 31: 2385-2392.

23. Angelidaki I and BK Ahring Methods for increasing the biogas potential from the recalcitrant organic matter contained in manure. Water Sci. Technol. 2000; 41: 189-194.

24. Palmowski $\mathbf{L}$ and $\mathbf{J}$ Müller Influence of the size reduction of organic waste on their anaerobic digestion. Water Sci. Technol. 2000; 41: 155-162.

25. Sasse L, Kellner $\mathbf{C}$ and A Kimaro Improved biogas unit for developing countries. Deutsche Gesellschaft für Technische Zusammenarbeit (GTZ) GmbH, Vieweg \& Sohn Verlagsgesellschaft Braunschweig. 1991.

26. Laramee J and J Davis Economic and environmental impacts of domestic biodigesters: Evidence from Arusha, Tanzania. Energ. Sustain. Dev. 2013; 17: 296304. 